\title{
LONG-TERM RISK CLASS MIGRATIONS OF NON-BANKRUPT AND BANKRUPT ENTERPRISES
}

\author{
Tomasz KOROL (1) \\ Faculty of Management and Economics, Gdansk University of Technology, Gdansk, Poland \\ Received 23 April 2019; accepted 10 February 2020
}

\begin{abstract}
This paper investigates how the process of going bankrupt can be recognized much earlier by enterprises than by traditional forecasting models. The presented studies focus on the assessment of credit risk classes and on determination of the differences in risk class migrations between non-bankrupt enterprises and future insolvent firms. For this purpose, the author has developed a model of a Kohonen artificial neural network to determine six different classes of risk. Long-term analysis horizon of 15 years before the enterprises went bankrupt was conducted. This long forecasting horizon allows one to identify, visualize and compare the intensity and pattern of changes in risk classes during the 15-year trajectory of development between two separate groups of companies (150 bankrupt and 150 non-bankrupt firms). The effectiveness of the forecast of the developed model was compared to three popular statistical models that predict the financial failure of companies. These studies represent one of the first attempts in the literature to identify the long-term behavioral pattern differences between future "good" and "bad" enterprises from the perspective of risk class migrations.
\end{abstract}

Keywords: risk classes, forecasting, bankruptcy, self-organizing maps, financial crisis, insolvency.

JEL Classification: G33, F37.

\section{Introduction}

In the literature, credit risk is mainly considered from the viewpoint of banks granting loans to companies (Bluhm et al., 2003; Schonfeld et al., 2018; Shimko, 2004). In practice, this risk also applies to companies providing trade credits to their partners. This risk is often defined as the probability of failure by the contractor to fulfill one or more contracts due to the inability to meet financial obligations. According to Wilner (2000), companies threatened with bankruptcy tend to take trade credits rather than bank loans. Therefore, the firm granting credits to their contractors should monitor the level of bankruptcy risk of their borrowers. No such monitoring may result in a situation in which a "healthy" business, as a result of problems with obtaining its receivables from bankrupt companies, will face the risk of bank-

*Corresponding author. E-mail: korol.tomasz@gmail.com 
ruptcy itself. Bankruptcy causes creditors of the insolvent firm to suffer losses in the form of uncollected receivables.

Corporate bankruptcy prediction is a well-researched area in finance. Thus far, a large number of models have been proposed, starting with the development of statistical models (Altman, 1968; Alaka et al., 2018; Barboza et al., 2017; Mihalovic, 2016; Psillaki et al., 2010; Kumar \& Ravi, 2007; Laitinen, 2007; Lukason \& Hoffman, 2014; Orsenigo \& Vercellis, 2013; Giannopoulos \& Sigbjornsen, 2019) through the implementation of artificial intelligence methods that very often originated from different scientific disciplines (Brabazon \& O’Neil, 2004; Dong et al., 2018; Hosaka, 2019; Flores-Jimeno \& Jimeno-Garcia, 2017; Xiao et al., 2012; Lin et al., 2014; Lensberg et al., 2006; Sun et al., 2014; Jardin, 2015; Wu et al., 2010; Tian \& Yu, 2017; Tsai, 2014; Ptak-Chmielewska, 2019; Kiang \& Kumar, 2001).

Despite the growing interest in corporate bankruptcy forecasting models, many questions remain unanswered. These models are not free from drawbacks and limitations, which are relatively rarely subject to substantive discussion in the literature. One of the important issues is their stability (Gavurova et al., 2017; Li \& Faff, 2019; Sayari \& Mugan, 2017; Grice \& Dugan, 2001; Ooghe \& Balcaen, 2006; Jardin \& Severin, 2011). Regardless of the modeling technique (linear or non-linear, regression or classification), models always have the same drawback of a short forecasting horizon. The standard models of forecasting corporate bankruptcy cannot predict horizons longer than two to three years before the failure. Nonetheless, in most cases, bankruptcy is a continuous process that can be divided into several stages, starting with the appearance of the first signs of crisis, continuing through blindness to and ignorance of the financial and non-financial symptoms of economic crisis and erratic behaviors, until the final phase of the crisis, which is insolvency. Additionally, taking into account that a company's collapse is the result of a set of causes, there is no one single reason that would be fully responsible for the bankruptcy of a given company. Thus, the author of this paper investigates how the process of going bankrupt can be recognized much earlier than in traditional forecasting models. The complexity and importance of this phenomenon in finance requires a comprehensive approach over a longer period of analyses. Therefore, the author set the following objectives for the present study:

1. To develop an universal, global model of self-organizing map (Kohonen model) with the assessment of six different risk classes for wide variety of enterprises from different regions of the world. Such a model with a risk map can enhance the prediction of financial failures in three ways. First, it can identify and visualize the long-term pattern of firm collapse (in the form of migration between individual classes); second, it can more precisely define the level of risk (the most popular previous multivariate discriminant analyses models only specify if the company is at risk with no identification of the level of such risk); and third, it can improve the stability of forecast effectiveness.

2. To identify the long-term differences between non-bankrupt and future bankrupt enterprises in the risk class migration process. The important question to answer is whether there are any significant differences in development and conducting business activities in a period as long as 15 years before the enterprises go into financial crisis. Examining the volatility of migrations between risk classes can reveal the first symptoms of going bankrupt long before the real bankruptcy risk occurs. 
3. To compare the effectiveness of the developed risk map with three traditional statistical bankruptcy forecasting models, including one discriminant analysis model, one logit model and one decision tree model. Such comparison let verify the usefulness of soft computing model in forecasting the risk of bankruptcy in situation of wide variety of economic conditions (global model) in comparison of traditional models that were estimated for specific economic region.

4. To develop specialized model of self-organizing map for group of enterprises from the same region. Such a model let compare the effectiveness of Kohonen model developed with global research approach and specialized area of forecast.

The paper consists of six sections. In the Introduction, the author presents the justification for the topic, the study objectives and the contribution and innovation to the literature. Section 1 describes the common types of bankrupt enterprises. Section 2 introduces this study's research assumptions. In Section 3, the author presents a developed model of selforganizing maps. The comparative analysis of effectiveness and the discussion of the results are presented in Section 4. Last section concludes the paper.

\section{Characteristics of the common types of bankrupting enterprises}

To improve the reliability and stability of the forecasting model, we first need to understand the common types of bankruptcy. Previous studies often ignore facts during the estimation of forecasting models. However, each type of bankruptcy is characterized by varying intensity of the collapse. By identifying and differentiating three or four different patterns of going into insolvency, we can enhance the forecasting properties of the model.

According to Ooghe and Prijcker (2008), who evaluated the causes of the crisis and the maturity of the enterprises that have collapsed, there are four main types of bankruptcy as follows:

- Type I applies to companies that are characterized by a failed start-up of operations. Such companies, since their foundation, have had problems with proper functioning. They suffer from a lack of effective management, have no strategic advantage factor over the competition, have poorly developed customer bases, and their products are not attractive to potential customers. These types of companies are never profitable, are characterized by low liquidity, and their bankruptcy is possible to forecast practically from the start of business. Such companies have a very small chance of survival from the beginning. Type I bankruptcy concerns young, inexperienced companies lacking adequate capital and intellectual resources to be able to function. This type of bankruptcy is consistent with findings from studies on the types of bankruptcy conducted by Burgelman (1991), Fichman and Levintahl (1991), and Kale and Arditi (1998).

- Type II refers to companies that have existed in the market for several years. Such companies are led by dynamic, ambitious management that did not have previous access to larger financial resources. Convincing banks to give them extra credit allows companies to execute investment plans. However, big ambitions and excessive optimism of the management cause the overestimation of the plan to achieve income from sales and to aggressively gain significant market share. Insufficient revenue growth 
does not allow such companies to pay their excessive commitments and operating costs. These companies are characterized by a weak structure of liabilities (excess liabilities with respect to equity held). This type of bankruptcy is consistent with the conclusions of the study by Argenti (1976).

- Type III applies to enterprises that initially are no different from type II firms. However, unlike the others, after the completion of the investment, they are successful in the market and gain market share. Their revenues significantly rise. Excessive optimism and ambition of management and the initial blindness due to achieved success cause the management to lose alertness and awareness of potential problems. The first symptoms of a deteriorating financial situation are ignored. In enterprises of this type, it is believed that this situation is temporary, and its origins lie outside the enterprise. Taking additional credits for the implementation of more ambitious targets causes some kind of "overheating" in the company. The collapse of the financial situation occurs. The company loses liquidity and, consequently, goes bankrupt (Laitinen \& Lukason, 2014).

- Type IV refers to enterprises that have operated in the market for a dozen years or more. Such companies are characterized by apathy and blindness. Managers do not notice a dynamically changing environment and growing competitive rivalry. Such companies operate on the basis of outdated policies, procedures, and plans that years ago allowed them to succeed. In the absence of the awareness of restructuring, these companies consequentially lose market share, reduce their profitability, and have problems with liquidity. This is the last warning. The lack of decisive action or even further apathy of managers of such enterprises inevitably leads to bankruptcy. This type of bankruptcy is also confirmed by the studies of Gilbert (2005) and Wiseman and Bromiley (1996).

An interesting approach to the characterization of the types of bankruptcy has been demonstrated by Moulton and Thomas (1996), who distinguish between four types of bankruptcy due to the rate of change of revenues in an industry in which the firm operates and the rate of change in returns on assets and sales volume of these companies. The four featured types of bankruptcy are presented in Figure 1.

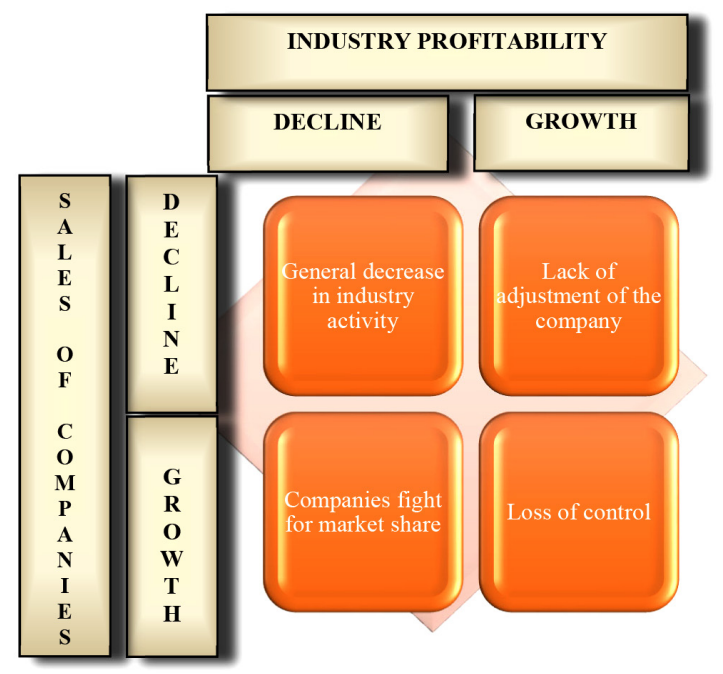

Figure 1. Types of corporate bankruptcy 
Along with the decline in the profitability of an industry, a competitive struggle between firms intensifies. Companies wanting to stay "alive" maintain sales by lowering prices. Further decreases in the attractiveness of the industry make the weaker companies unable to withstand competitive pressures, which causes their collapse. This type of bankruptcy has also been highlighted in studies by Jayasekera (2018), Hambrick and D'Aveni (1988), Argenti (1976) and Zammuto and Cameron (1985).

Another type of bankruptcy occurs in the case of increasing profitability of the industry, but when the company's profitability decreases. This may be the case for the consolidation of the industry, where weaker companies are forced out of it. Additionally, the entrance of a large company into an attractive industry can cause the bankruptcy of companies with a weaker position. This type of bankruptcy is also perceived in the research by Utterback and Suarez (1993).

The next type of bankruptcy applies to companies operating in an industry with decreasing profitability. Such companies increase their sales through price wars. The intense price war, especially in the case of high barriers to exit from the sector, leads to a devastating battle between companies. In this case, only the companies with the strongest market positions are able to survive.

The last type of bankruptcy defined by Moulton and Thomas refers to companies that, despite the increasing sales of products and the increasing profitability of the industry, go bankrupt. The reason for their bankruptcy may be their blindness due to achieved success. Poor estimation of future investments and demand for company products as well as company mismanagement cause the financial crisis. The nature of this type of bankruptcy is similar to the fourth kind of bankruptcy of companies described above, as defined by Ooghe and Prijcker.

The original division of insolvent companies into four different types of bankruptcy was suggested by Richardson, Nwankwo and Richardson (1994) in studies using the metaphor of a "frog". They distinguished the following types of "frogs" - insolvent companies:

- "Boiled frog" - This type of bankruptcy applies to businesses that have operated in the market for at least several years. A characteristic feature of such companies is that the board is satisfied with themselves. The company is "blind" to changes in the environment. The board is helplessly stuck in old strategic, tactical and operational plans. Johnson (1988) describes this phenomenon as a "strategic drift". According to him, the paradigm of no change and a kind of inactivity in the company leads to the creation of a strategic gap between changes in the surroundings of the company and the company "drifting" in place. This type of bankruptcy is consistent with the theory presented earlier by Ooghe and Prijcker (type IV bankruptcy).

- "Drowned frog" - This type of bankruptcy shows that companies led by highly ambitious managers who, upon succeeding in a particular field, are strongly motivated to aggressively expand into new markets and business areas. The arrogance and the original success are at the base of this type of bankruptcy. The dynamic expansion of the company in all directions means that, at some point, this extra range of operations of the enterprise is not related to core resources, which ensured the earlier success of the company. Despite the fact that, very often, sales in such companies are rapidly growing, it is done at the expense of reducing the prices of products. In this type of 
bankruptcy, the collapse of the financial situation is sudden and very intense. This type of bankruptcy is consistent with the second type of bankruptcy described by Ooghe and Prijcker.

- "Tadpole" represents the bankruptcy of a company that has a failed start-up operation. Therefore, it applies to young companies. A number of potential causes of this type of company bankruptcy include the following:

- overly optimistic assumptions for the plan concerning revenues on sales, obtained profits, gained market share, and the attractiveness of the company's offer, and

- low levels of entrepreneurship of owners or managers. Often innovators emphasize the importance of inventing a new product but devote little energy to plan its sales and marketing strategy. They think that somehow the product will sell itself. Here, one can also find a convergence of the described type of bankruptcy with type I described by Ooghe and Prijcker.

- "Toad" - This type of bankruptcy applies to businesses operating for at least several years. It concerns megalomaniac companies that always focus on past successes. Managers are characterized by megalomania on one hand and apathy towards changes in the environment on the other. The management of the company is based more on the beliefs and faith of the board about an ongoing success rather than real analysis. Some features of this type of bankruptcy are also consistent with the fourth type of bankruptcy defined by Ooghe and Prijcker.

\section{Research assumptions}

\subsection{Variable and sample selection}

The application of statistical methods and soft computing techniques to forecasting the financial situation of enterprises requires the adequate preparation of sets of examples on which the model will be trained and tested. Each of them must contain information describing the situation of the company in the form of input variables as financial ratios. In the study, the author created 2 populations of enterprises. The first population used data on 400 enterprises from countries around the world, including: the USA, the U.K., Canada, France, Germany, Spain, Finland, Poland, Italy, Sweden, Taiwan, China, Japan, Mexico, Colombia, Argentina, Brazil, and Chile. The second population consists data on 200 firms from EU region. In both populations the companies were firms from the service and manufacturing sector. The objective of the first population was to create global, universal forecasting model for wide variety of firms from different regions of the world. The aim of second population was to develop specialized model for risk forecasting for only European firms and then to able to compare their effectiveness and verify the abilities of self-organizing map for universal bankruptcy risk predictions.

For the learning process of global model, a learning sample consisting of 50 bankrupt and 50 non-bankrupt enterprises was created. To test the effectiveness of the model based on unknown companies from the model, the testing sample was created. This sample included 150 enterprises at risk of bankruptcy and 150 firms with good financial conditions. In case of specialized model, the learning sample consisted 25 bankrupt and 25 non-bankrupt firms and the testing sample consisted 75 bankrupt and 75 non-bankrupt firms. The fact that 
the company is in a good financial situation was assumed based on the overall analysis of financial statements. In the assessment, profitability, liquidity and debt ratios were mainly considered. The companies were selected for which there was no doubt that they are not at risk of falling. The enterprises at risk of bankruptcy were chosen based on the following three criteria:

- information from the firm's authorities about the threat of collapse,

- court judgments declaring bankruptcy, and

- liquidation of the company.

For all 600 enterprises, the author calculated the value of 30 financial ratios for the last 15 years before the moment that the company was at risk of bankruptcy or was considered a good firm. Depending on the company, the 15-year financial statements taken for analysis covered the period from 1995 to 2016. The complete list of used input variables of the model is presented in Table 1 .

Financial statements contain very rich economic content about given companies, which through various financial ratios can be used in the models predicting the risk of bankruptcy of firms. The value of analysis is determined by indicators with high information capacity, and therefore there is a tendency to reduce their number and group them properly (e.g. Altman, 2018; Delen et al., 2013; Dong et al., 2018; Laitinen et al., 2014; Liang et al., 2016; Ooghe \& Balcaen, 2006; Tian et al., 2015; Tian \& Yu, 2017).

Table 1 . The financial ratios used in the study

\begin{tabular}{|c|l|}
\hline \multicolumn{1}{|c|}{ Symbol of input variable } & \multicolumn{1}{c|}{ Computing formula } \\
\hline \multicolumn{2}{|c|}{ Profitability ratios } \\
\hline X1 & Profit on sales / total assets \\
\hline X3 & (net income + depreciation) / total liabilities \\
\hline X10 & Income before tax / current liabilities \\
\hline X13 & Income before tax / total revenues \\
\hline X15 & Net income / total assets \\
\hline X16 & EBIT / total assets \\
\hline X19 & EBIT / interest paid \\
\hline X22 & Operating income / revenues from sales \\
\hline X23 & Profit on sales / stockholders' equity \\
\hline X24 & Net income / stockholders' equity \\
\hline X25 & Income before tax / revenues from sales \\
\hline & \multicolumn{1}{|c|}{ Activity ratios } \\
\hline X4 & Operational costs / current liabilities \\
\hline X7 & Total revenues / total assets \\
\hline X14 & Inventories / total revenues \\
\hline X21 & $\begin{array}{l}\text { (quick assets - current liabilities) / daily operating expenses } \\
\text { with the denominator proxied by (sales - income before taxes - } \\
\text { depreciation) / 365 }\end{array}$ \\
\hline X26 & Total revenues / short-term receivables \\
\hline & \multicolumn{2}{|c|}{} \\
\hline &
\end{tabular}


End of Table 1

\begin{tabular}{|c|l|}
\hline Symbol of input variable & \multicolumn{1}{c|}{ Computing formula } \\
\hline X27 & \multicolumn{1}{c|}{ Short-term receivables / current liabilities } \\
\hline & \multicolumn{1}{c|}{ Liquidity ratios } \\
\hline X2 & (current assets - current liabilities) / total assets \\
\hline X8 & Current assets / current liabilities \\
\hline X12 & (Current assets - inventories) / current liabilities \\
\hline X18 & Cash / total assets \\
\hline X28 & Cash / current liabilities \\
\hline & \multicolumn{1}{|c|}{ Structural and debt ratios } \\
\hline X5 & Stockholders' equity / total liabilities \\
\hline X6 & (stockholders' equity + noncurrent liabilities) / fixed assets \\
\hline X9 & Current liabilities / total assets \\
\hline X11 & Total assets / total liabilities \\
\hline X17 & Current liabilities / stockholders' equity \\
\hline X20 & Current assets / total liabilities \\
\hline X29 & Stockholders' equity / total assets \\
\hline X30 & Fixed assets / total assets \\
\hline &
\end{tabular}

\subsection{Basic concepts of Kohonen model}

The self-organizing map (SOM) is a non-parametric neural network with a desirable combination of data abstraction and spatialization. It is widely used for visual clustering in a wide range of applications (Chen et al., 2013). It is an unsupervised neural network proposed by Kohonen (1982) for visual cluster analysis. The term artificial neural network refers to the mathematical model of a complex network of computing nodes called neurons and their connections that imitate the actions of biological systems that can effectively solve specific problems. In contrast to the traditional statistical forecasting models (e.g., multivariate discriminant analysis), the operations of a neural network are a purely mechanical approach to the analyzed phenomenon without the detection of internal relationships and the strength of existing relationships. Kohonen networks are a specific group of neural networks used in the process of classification and the grouping of data. They usually consist of a layer of input neurons and a single processing layer. Each neuron in the processing layer is connected to all inputs. The neurons of the map are located on a regular grid embedded in a low (usually 2 or 3 ) dimensional space and are associated with the cluster prototypes by the connected weights. Each input vector is classified using the method of "nearest neighbor". In the course of the learning process, the neurons compete with each other through the best matching principle in such way that the input is projected to the nearest neuron given a defined distance metric. The Kohonen algorithm that learns the SOM network introduces the concept of neighborhood neurons. It is understood in the sense of the geometric position with respect to the winner neuron. The weights of neurons located close to the winner are modified to be stronger than the more distant neurons. This effect is implemented by using the neighbor- 
hood function. The winner neuron and its neighbors on the map are adjusted towards the input in proportion with the neighborhood distance. Consequently, the neighboring neurons likely represent the similar patterns of the input data space (Chen et al., 2013).

An example of the structure of the SOM network is shown in Figure 2. The learning process is unsupervised. Training data do not contain any information about the desired outputs. The network is designed to independently classify the data based only on the the correlation occurring in them.

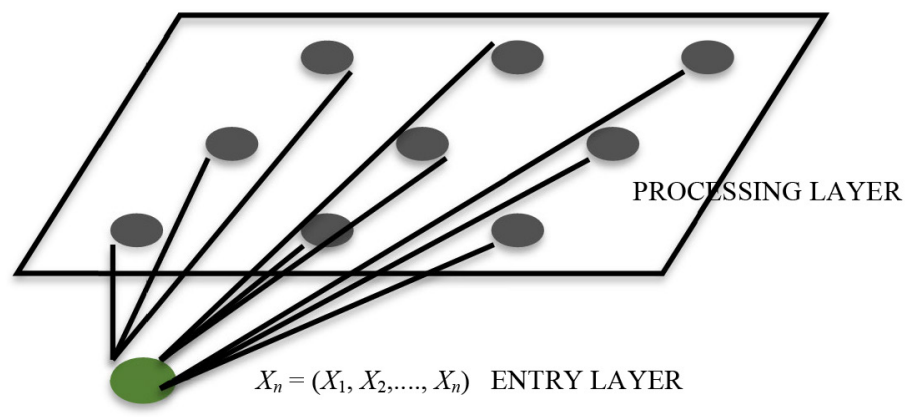

Figure 2. An example of the structure of a self-organizing maps (SOM)

As shown in Figure 2, in the SOM, the neurons of the input layer are connected with all the neurons of the output layer through synaptic weights. Thus, it is possible to establish a bi-dimensional map of different zones, such as failing and non-failing regions, and create risk classes.

Recent studies (Jardin \& Severin, 2011; Iturriaga \& Sanz, 2015; Chen et al., 2013) show the advantages of using a self-organizing map for short- and medium-term forecasting compared to the traditional forecasting models. Those researchers used the Kohonen network to predict the corporate collapse at horizons from one to five years.

In contrast to the statistical models, models of soft computing techniques such as SOM models effectively deal with imprecisely defined problems, incomplete data, imprecision and uncertainty (Acosta-González \& Fernández-Rodríguez, 2014). The issue of predicting bankruptcy of companies has all of the above characteristics. In addition, these methods are suitable for use in systems which are designed to fit certain internal parameters to changing environmental conditions in a dynamic way (so-called learning systems). The difference between the traditional calculation methods and soft computing methods is based on reference to issues such as precision, reliability and accuracy. Soft computing techniques tolerate data imprecision, uncertainty and approximation. The essence of models based on computational intelligence is processing and interpretation of data of various nature (Zapranis \& Ginoglou, 2000). That is why author of the research conducts this study to verify the possibility of creating SOM model for population of enterprises from different economic regions.

\subsection{Traditional statistical forecasting models used in the studies}

To compare the effectiveness of two developed SOM models with other bankruptcy forecasting models, the author has chosen three popular traditional models from the existing 
literature. To provide a variety of comparisons, each model taken is from a different region of the world where it was estimated, with different types of ratios used, and different forecasting techniques implemented. For all three models, the computing formulas for the ratios are given in Table 1.

The first model is the logit model (LOG) from North America estimated by Altman and Sabato (2007) and is based on 432 enterprises from that region:

$$
\mathrm{Z}=4.28+0.08 \times \mathrm{X} 15+0.18 \times \mathrm{X} 16-0.01 \times \mathrm{X} 17+0.02 \times \mathrm{X} 18+0.19 \times \mathrm{X} 19 .
$$

The cutoff point of this model is the value of 0.5 . It means that results above 0.5 indicate a high risk of financial failure (between $50 \%$ and $100 \%$ probability), and scores below 0.5 indicate a low risk of bankruptcy (between $0 \%$ and 50\%).

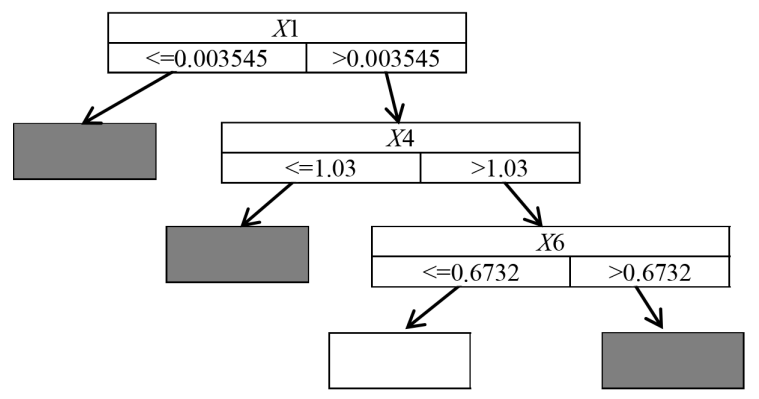

Figure 3. Structure of the decision tree model

The next model is the multivariate discriminant analysis model (MDA). It was constructed by Taffler for forecasting the financial failure of British enterprises. It has following function (Agarwal \& Taffler, 2007) with a solvency threshold of ZT $=0$ :

$$
\mathrm{ZT}=3.2-10.68 \times \mathrm{X} 9+12.18 \times \mathrm{X} 10+2.5 \times \mathrm{X} 20+0.029 \times \mathrm{X} 21 .
$$

The last model is the decision tree model (CR\&T) estimated for European enterprises by Korol (2013). The structure of the model is presented in Figure 3. The gray areas represent the classification of a company in danger of bankruptcy, and the white area shows the classification of non-bankrupt firms.

\section{Corporate bankruptcy forecasting model}

Inputs to both SOM models are based on the correlation matrix by choosing only the features that are poorly correlated with each other and strongly correlated with the grouping variable, representing the information about the risk of bankruptcy. This approach ensured the selection of such features, which do not duplicate information provided by other financial ratios, while being good representatives of the ratios not selected as diagnostic. Using a learning sample consisting of 100 companies described by chosen 15 financial ratios (from X1 to X15 from Table 1), a global model of self-organizing maps of size 10 neurons (rows) x 10 neurons (column) was developed, as shown in Figure 4. 
On the map, the author distinguished the following 6 risk classes:

- A - the highest level of credibility (a company with outstanding good credit reliability),

- B - very good solvency of the enterprise,

- C - average solvency capabilities with visible risk,

- D - the possible repayment of liabilities, increased uncertainty, and problematic credit exposure,

- E - Liabilities are at high risk, and the company is vulnerable to bankruptcy, and

- F - the bankrupt company with unacceptable risk.

As a result, the manager can use this map not only to evaluate the risk of bankruptcy of the analyzed company but also to assess the good financial situation of the company and to visualize the trajectory of the risk class migrations during the "life" of the enterprises. In addition, the black, bold line is the distinguishing area at which the company is at risk of bankruptcy and the zone of good economic situation of enterprises.

Due to the limited size of the paper, it is not possible to present the received trajectories for all 300 enterprises from the testing sample. To explain the range of possibilities of using the developed risk map, one example of the trajectory of a bankrupt firm is presented in Figure 4.

The trajectory of this company (red arrows identify the year analyzed before bankruptcy in brackets) clearly presents a systematic increase in the risk of financial failure for the firm. A gradual decrease of the solvency capability can be seen, which shows the four visible stages of going bankrupt. During the period from 15 to 11 years before bankruptcy, the situation was classified as "B" class, indicating very good solvency of this enterprise. In the second stage (the $10^{\text {th }}, 9^{\text {th }}$ and $8^{\text {th }}$ years before bankruptcy), the first symptoms of the financial crisis risk have started to be visible. The risk class migrated from " $\mathrm{B}$ " to " $\mathrm{C}$ ", indicating average solvency capabilities with visible risk. The crucial period for the analyzed firm was the $7^{\text {th }}$ year before bankruptcy. At that time, the enterprise crossed the "bold line" on the map of the self-organizing network. The movement from risk class "C" (neuron 6×7) to "D" (neuron $5 \times 7)$ can be seen, showing the beginning of the third stage of going bankrupt. During the

\begin{tabular}{|c|c|c|c|c|c|c|c|c|c|}
\hline $\mathrm{C}$ & $\mathrm{C}$ & $\mathrm{D}$ & $\mathrm{D}$ & $\mathrm{D}$ & $\mathrm{E}$ & $\mathrm{E}$ & $\mathrm{F}$ & $\mathrm{F}$ & $\mathrm{F}$ \\
\hline $\mathrm{C}$ & $\mathrm{C}$ & $\mathrm{D}$ & $\mathrm{D}$ & $\mathrm{D}$ & $\mathrm{D}$ & $\mathrm{E}$ & $\mathrm{F}$ & $\mathrm{F}(4)$ & $\mathrm{F}(3,2,1)$ \\
\hline $\mathrm{B}$ & $\mathrm{C}$ & $\mathrm{C}$ & $\mathrm{C}$ & $\mathrm{C}$ & $\mathrm{D}$ & $\mathrm{E}$ & $\mathrm{F}$ & $\mathrm{F}$ & $\mathrm{F}$ \\
\hline $\mathrm{B}$ & $\mathrm{B}$ & $\mathrm{B}(11)$ & $\mathrm{B}$ & $\mathrm{C}$ & $\mathrm{D}$ & $\mathrm{E}$ & $\mathrm{E}$ & $\mathrm{E}$ & $\mathrm{E}$ \\
\hline $\mathrm{B}$ & $\mathrm{B}$ & $\mathrm{B}$ & $\mathrm{A}$ & $\mathrm{C}$ & $\mathrm{D}$ & $\mathrm{D}(7)$ & $\mathrm{D}$ & $\mathrm{E}(6,5)$ & $\mathrm{E}$ \\
\hline $\mathrm{B}$ & $\mathrm{B}$ & $\mathrm{B}$ & $\mathrm{B}(13,12)$ & $\mathrm{C}$ & $\mathrm{C}(10)$ & $\mathrm{C}(9,8)$ & $\mathrm{D}$ & $\mathrm{E}$ & $\mathrm{E}$ \\
\hline $\mathrm{A}$ & $\mathrm{A}$ & $\mathrm{A}$ & $\mathrm{A}$ & $\mathrm{B}$ & $\mathrm{B}$ & $\mathrm{C}$ & $\mathrm{D}$ & $\mathrm{D}$ & $\mathrm{D}$ \\
\hline $\mathrm{A}$ & $\mathrm{A}$ & $\mathrm{A}$ & $\mathrm{A}$ & $\mathrm{B}(14)$ & $\mathrm{B}$ & $\mathrm{C}$ & $\mathrm{D}$ & $\mathrm{D}$ & $\mathrm{D}$ \\
\hline $\mathrm{A}$ & $\mathrm{A}$ & $\mathrm{A}$ & $\mathrm{A}$ & $\mathrm{B}$ & $\mathrm{B}$ & $\mathrm{C}$ & $\mathrm{C}$ & $\mathrm{C}$ & $\mathrm{C}$ \\
\hline $\mathrm{A}$ & $\mathrm{A}$ & $\mathrm{A}$ & $\mathrm{A}$ & $\mathrm{B}(15)$ & $\mathrm{B}$ & $\mathrm{B}$ & $\mathrm{C}$ & $\mathrm{C}$ & $\mathrm{C}$ \\
\hline
\end{tabular}

Figure 4. Map of the self-organizing network with designated classes of risk of bankruptcy for global population of enterprises 
next two years ( $6^{\text {th }}$ and $5^{\text {th }}$ year), the risk continued to increase. The company was classified as risk class "E" (neuron $5 \times 9$ ), indicating a high risk of bankruptcy. The fourth stage of the path of going into liquidation began 4 years before the enterprise went into real bankruptcy. The developed model effectively predicted in advance that bankruptcy was inevitable, and the risk was unacceptable (risk class "F") at neurons $2 \times 9$ and $2 \times 10$. In the process of estimation of SOM model only for European enterprises (the specialized model) the same research procedure was implemented. With the use of correlation matrix also the financial ratios from $\mathrm{X} 1$ to $\mathrm{X} 15$ were chosen. It is the sign that this set of ratios has the highest discrimination abilities to differentiate the bankrupt from non-bankrupt enterprises. The developed model is presented in Figure 5. This model also consists 6 risk classes (from A to F) but the allocation of them is different as shown in Figure 5.

\begin{tabular}{|c|c|c|c|c|c|c|c|c|c|}
\hline C & C & C & C & D & D & E & F & F & F \\
\hline C & C & C & C & D & D & E & F & F & F \\
\hline B & B & B & B & C & D & E & F & F & F \\
\hline B & B & B & B & C & D & E & E & E & E \\
\hline B & B & B & B & B & C & C & D & D & D \\
\hline A & A & A & A & A & B & B & C & D & D \\
\hline A & A & A & A & A & B & B & C & D & D \\
\hline A & A & A & A & A & B & B & C & C & C \\
\hline A & A & A & A & A & B & B & C & C & C \\
\hline A & A & A & A & A & B & B & C & C & C \\
\hline
\end{tabular}

Figure 5. Map of the self-organizing network with designated classes of risk of bankruptcy for European firms

It is important to note that although the structure of the self-organizing map is the same for both samples of firms $(10 \times 10$ neurons), the number of specific risk classes differ in two models. As it can be seen, the highest number of high-risk bankruptcies classes D, E and F occurs in the global SOM model for wide variety of enterprises. The global model consists as much as 40 such risk classes while the European SOM model consists only 29.

\section{Results and discussion}

To evaluate the effectiveness of the created models, the following formula was used (the symbols are explained in Table 2):

$$
\mathrm{S}=\{1-[(\mathrm{D} 1+\mathrm{D} 2) /(\mathrm{BR}+\mathrm{NBR})]\} \times 100 \% .
$$

It should be stressed that, from the point of view of individual stock investors, banks, lenders or investment funds, in addition to analyzing the overall effectiveness $(S)$ of the model, it is important to distinguish different types of errors generated by the model. The author has used the classification matrix presented in Table 2 with the identification of two kinds of errors, Type I and Type II. Type I error indicates the classification of a future bankrupt enterprise as a good firm. Buying shares or giving credit to a future bankrupt firm (Type 
I error) will result in losses initially due to the decrease in prices of shares of the company, its liquidation and the problems of collecting back the previously given credit. Conversely, Type II error means the loss of "only" potential profits by deciding not to purchase the shares of "healthy" companies believing that this is a future bankrupt company. For this reason, from the point of view of cost generating errors, it is more important to consider Type I error than Type II.

Table 2. Classification matrix of bankruptcy risk forecasting models

\begin{tabular}{|c|l|l|}
\hline Pctual status & \multicolumn{1}{|c|}{ Bankrupt } & \multicolumn{1}{|c|}{ Non-bankrupt } \\
\hline Bankrupt & TRUE & $\begin{array}{l}\text { Type I error } \\
\text { E1 = D1 / BR } \times 100 \% \text {, where D1 } \\
\text { is the number of bankrupted firms } \\
\text { classified by the model as non- } \\
\text { bankrupt company, and BR is the } \\
\text { number of bankrupt enterprises in } \\
\text { the sample. }\end{array}$ \\
\hline Non-bankrupt & $\begin{array}{l}\text { Type II error } \\
\text { E2 = D2 / NBR } \times 100 \%, \text { where } \\
\text { D2 is the number non-bankrupt } \\
\text { companies classified by the } \\
\text { model as a company at risk of } \\
\text { bankruptcy, and NBR is number } \\
\text { non-bankrupt firms in the sample. }\end{array}$ & \multicolumn{1}{|c}{ TRUE } \\
\hline
\end{tabular}

When evaluating the effectiveness of the developed global SOM model (Table 3), it can be seen that one year, two years and three years before bankruptcy, the model achieved outstanding results with over $89 \%$ of enterprises correctly classified in the testing sample. By extending the period of analysis to the fourth, fifth, sixth and seventh year before bankruptcy, the effectiveness is decreased and fluctuated from $79.67 \%$ to $85 \%$. In the literature, correct classifications at the level of eighty-plus percent are still considered as very good results. Extending the forecast horizon for another three years (the $10^{\text {th }}, 9^{\text {th }}$ and $8^{\text {th }}$ year before bankruptcy), there was a further decline in effectiveness to the level between $66 \%$ and $69 \%$. It is also important to note that until the fifth year before bankruptcy, Type I error was smaller than $20 \%$, while during the forecasting horizon of one year and two years before this error, it was only $4 \%$ and $6 \%$, respectively. This finding is further proof of the very good predictive properties of constructed model.

It must be clearly stated that many of these companies were not at risk of bankruptcy eight years (or longer) before they went bankrupt. For this reason, another advantage of the created model is that it can be used for the identification of the first bankruptcy symptoms in a company, since the bankruptcy process is based on the intensity of migrations between class risks. By using this approach, it will be possible to identify the risks of bankruptcy long before the company enters into the real bankruptcy process and much earlier than the traditional forecasting models identify such risk. Figure 6 presents the risk class migrations for 150 nonbankrupt (left side) and 150 bankrupt enterprises (right side) during the 15 years of analysis. 
Table 3. The results of the classification of enterprises based on the testing sample of the SOM model (in parentheses is the number of misclassified firms)

\begin{tabular}{|l|c|c|c|c|c|c|c|c|}
\hline \multicolumn{1}{|c|}{ Years before } & 15 & 14 & 13 & 12 & 11 & 10 & 9 & 8 \\
\hline Type I error & $\begin{array}{c}61.33 \% \\
(92)\end{array}$ & $\begin{array}{c}58.67 \% \\
(88)\end{array}$ & $\begin{array}{c}52.0 \% \\
(78)\end{array}$ & $\begin{array}{c}51.33 \% \\
(77)\end{array}$ & $\begin{array}{c}50.0 \% \\
(75)\end{array}$ & $\begin{array}{c}47.33 \% \\
(71)\end{array}$ & $\begin{array}{c}46.0 \% \\
(69)\end{array}$ & $\begin{array}{c}44.67 \% \\
(67)\end{array}$ \\
\hline Type II error & $\begin{array}{c}21.33 \% \\
(32)\end{array}$ & $\begin{array}{c}24.0 \% \\
(36)\end{array}$ & $\begin{array}{c}23.33 \% \\
(35)\end{array}$ & $\begin{array}{c}24.67 \% \\
(37)\end{array}$ & $\begin{array}{c}23.33 \% \\
(35)\end{array}$ & $\begin{array}{c}18.67 \% \\
(28)\end{array}$ & $\begin{array}{c}22.0 \% \\
(33)\end{array}$ & $\begin{array}{c}17.33 \% \\
(26)\end{array}$ \\
\hline Overall effect. & $58.67 \%$ & $58.67 \%$ & $62.33 \%$ & $62.00 \%$ & $63.33 \%$ & $67.00 \%$ & $66.00 \%$ & $69.00 \%$ \\
\hline Years before & 7 & 6 & 5 & 4 & 3 & 2 & 1 \\
\hline Type I error & $\begin{array}{c}24.67 \% \\
(37)\end{array}$ & $\begin{array}{c}23.33 \% \\
(35)\end{array}$ & $\begin{array}{c}19.33 \% \\
(29)\end{array}$ & $\begin{array}{c}16.0 \% \\
(24)\end{array}$ & $\begin{array}{c}11.33 \% \\
(17)\end{array}$ & $\begin{array}{c}6.0 \% \\
(9)\end{array}$ & $4.0 \%(6)$ \\
\hline Type II error & $\begin{array}{c}16.0 \% \\
(24)\end{array}$ & $\begin{array}{c}15.33 \% \\
(23)\end{array}$ & $\begin{array}{c}16.0 \% \\
(24)\end{array}$ & $\begin{array}{c}14.0 \% \\
(21)\end{array}$ & $\begin{array}{c}10.67 \% \\
(16)\end{array}$ & $\begin{array}{c}11.33 \% \\
(17)\end{array}$ & $7.33 \%(11)$ \\
\hline Overall effect. & $79.67 \%$ & $80.67 \%$ & $82.33 \%$ & $85.00 \%$ & $89.00 \%$ & $91.33 \%$ & $94.33 \%$ \\
\hline
\end{tabular}

The non-bankrupt firms are characterized by the stability of their risk class classification. It can be seen that the majority of them (between 115 and 140 firms) were classified into three safe classes, "A", "B" or " $\mathrm{C}$ ". It is also important to note that throughout the whole forecasting horizon of 15 years, there are no major migrations between these classes. On the left-bottom of Figure 6 and in the details of Figure 8, the distribution of non-bankrupt firms
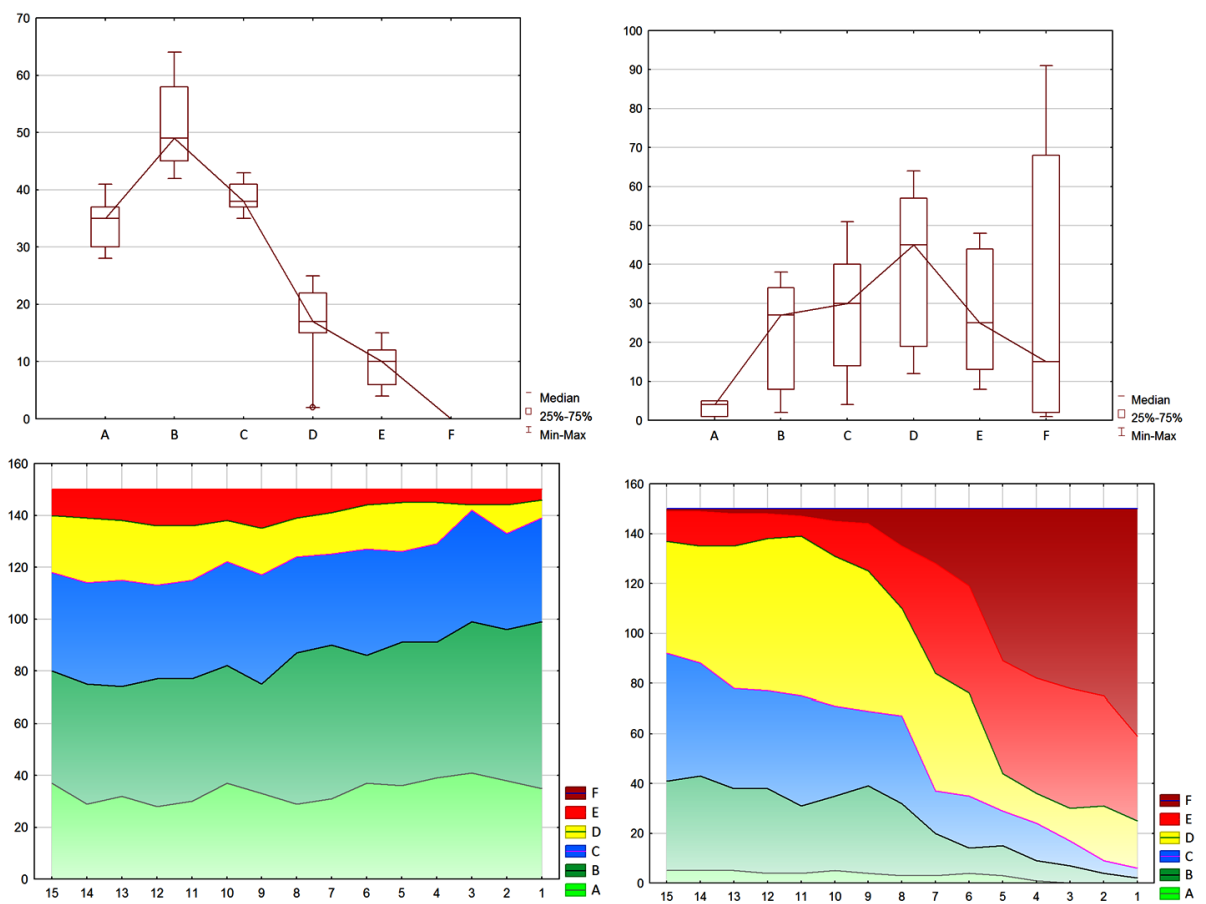

Figure 6. Risk class migrations of non-bankrupt enterprises (left side) and bankrupt firms (right side) during the 15 years of analysis in the global testing sample 
into risk classes is visualized. During the forecasting horizon of 15 years, "good" companies were classified into the following amounts:

- risk class "A" from 28 to 41 firms,

- risk class "B" from 42 to 64 companies, and

- risk class "C" from 35 to 43 entities.

No "healthy" enterprises were classified into the worst risk class "F" during the whole period of analysis. Those in risk classes "E" and "D" fell from 11 to 37 firms (they were Type II errors generated by the model).

Distribution of bankrupt enterprises into risk classes

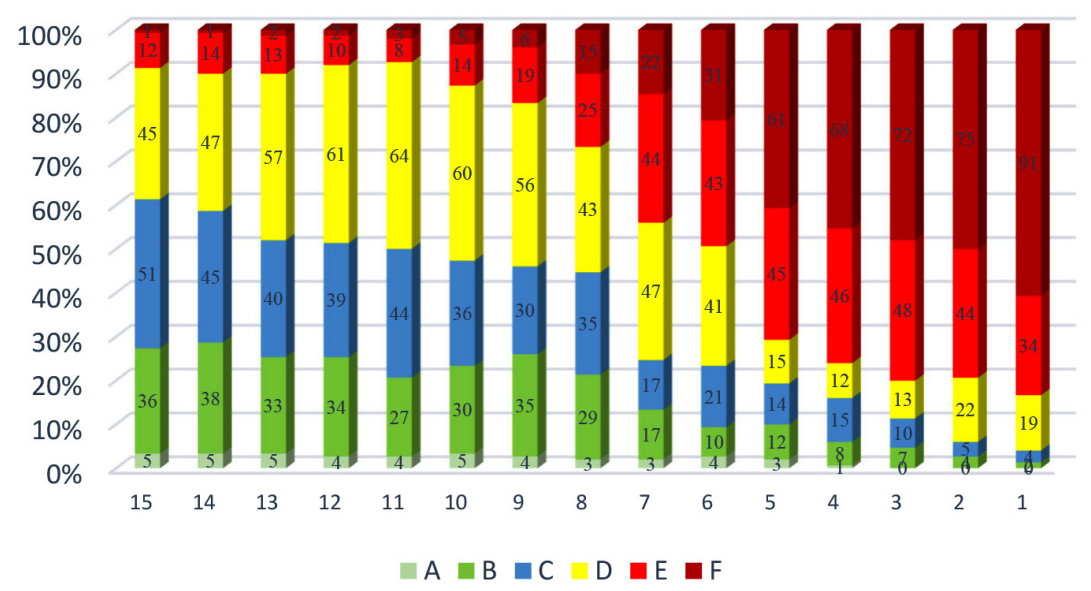

Figure 7. Distribution of bankrupt enterprises into risk classes during the 15 years of analysis in the global testing sample

In the case of 150 bankrupt enterprises, the high intensity of migrations between risk classes is clearly visible (Figure 6 and Figure 7). Fifteen years before the bankruptcy, 13 firms fell into the two worst risk classes, " $F$ " and "E". These entities probably represent those described in Section 2 of this paper by the first type of bankruptcy described by Ooghe and Prijcker as those companies with failed start-up operations. All the risk classes besides risk class "A" (into this class only up to 5 entities were assigned) are characterized by huge migrations as follows:

- risk class "B" - 15 years before bankruptcy 36 firms, 1 year before only 2 entities,

- risk class "C" - 15 years before bankruptcy 51 companies, 1 year before only 4 firms,

- risk class "D" - 15 years before bankruptcy 45 entities, 1 year before 19 enterprises,

- risk class "E" - 15 years before bankruptcy 12 firms, 1 year before 34 firms, and

- risk class "F" - 15 years before bankruptcy 1 company, 1 year before as many as 91 firms.

The above observations confirm the high usability of the proposed model in terms of both high effectiveness and possibility of identification of the pattern of going into the bankruptcy process. To prove high effectiveness of the presented SOM model, the author has conducted a comparative analysis of effectiveness of three traditional forecasting models presented in Section 3.3 of this paper. The results for the forecasting horizon of 15 years are shown in Table 4 . 
Distribution of non-bankrupt enterprises into risk classes

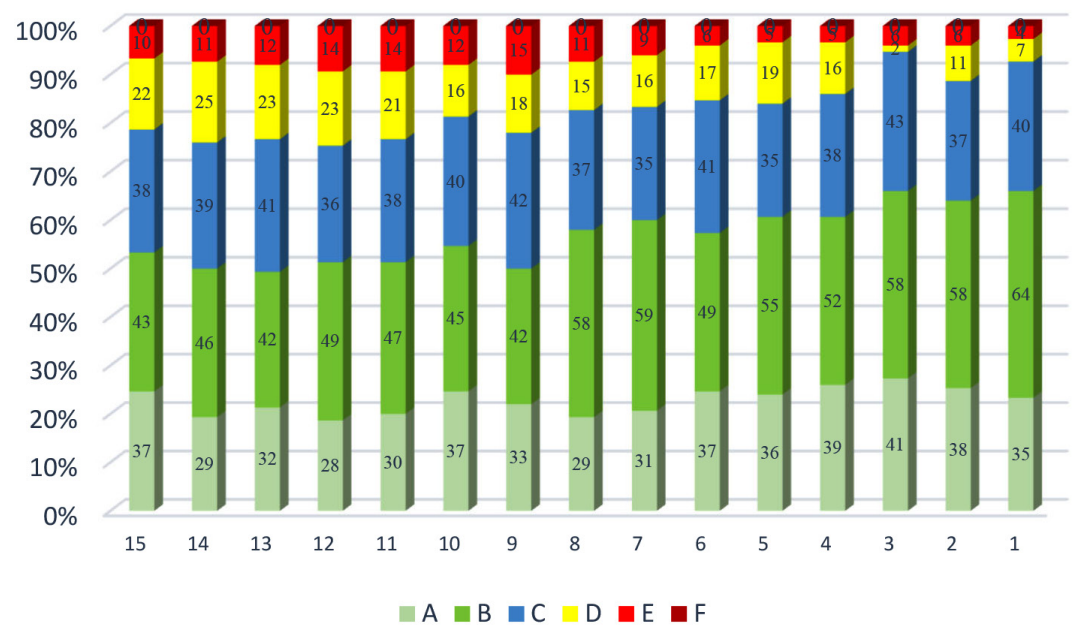

Figure 8. Distribution of non-bankrupt enterprises into risk classes during the 15 years of analysis in the testing sample

All three models (CR\&T, logit, and multivariate discriminant analysis) are characterized by high effectiveness in the forecasting periods of one year and two years before bankruptcy (between $85.33 \%$ and 89\%). However, in the forecasting horizon of three and four years before bankruptcy, the traditional models generate much worse results than the SOM model (the created SOM model has similar effectiveness as late as at the $8^{\text {th }}$ year before bankruptcy).

Table 4. The results of the classification of enterprises based on the testing sample of three statistical models

\begin{tabular}{|c|c|c|c|}
\hline Type of model & $\begin{array}{c}\text { Agarwal and Taffler } \\
2007(\mathrm{MDA})\end{array}$ & $\begin{array}{c}\text { Altman and Sabato } \\
2007(\mathrm{LOG})\end{array}$ & Korol 2013 (CR\&T) \\
\hline 1 & $87.33 \%$ & $89.0 \%$ & $88.67 \%$ \\
\hline 2 & $85.33 \%$ & $87.0 \%$ & $86.33 \%$ \\
\hline 3 & $76.67 \%$ & $77.67 \%$ & $77.33 \%$ \\
\hline 4 & $68.33 \%$ & $68.67 \%$ & $69.33 \%$ \\
\hline 5 & $67.33 \%$ & $68.33 \%$ & $68.0 \%$ \\
\hline 6 & $65.0 \%$ & $66.0 \%$ & $66.33 \%$ \\
\hline 7 & $64.33 \%$ & $65.33 \%$ & $65.0 \%$ \\
\hline 8 & $68.0 \%$ & $66.33 \%$ & $67.33 \%$ \\
\hline 9 & $62.67 \%$ & $63.33 \%$ & $63.0 \%$ \\
\hline 10 & $61.67 \%$ & $62.67 \%$ & $62.33 \%$ \\
\hline 11 & $66.0 \%$ & $61.67 \%$ & $57.0 \%$ \\
\hline 12 & $57.33 \%$ & $57.0 \%$ & $55.33 \%$ \\
\hline 13 & $58.67 \%$ & $58.0 \%$ & $56.33 \%$ \\
\hline 14 & $59.67 \%$ & $63.33 \%$ & $56.67 \%$ \\
\hline 15 & $61.33 \%$ & $62.67 \%$ & $57.33 \%$ \\
\hline
\end{tabular}


Looking at the results achieved by traditional forecasting models (Table 4), we can see that one year, two years and three years before bankruptcy the highest effectiveness obtained logit model of Altman and Sabato $(89.00 \%, 87.00 \%$ and $77.67 \%$ respectively). Four years before insolvency the highest effectiveness achieved decision tree model of Korol (69.33\%). As it was concluded before, in the forecasting horizon longer than four years all three models generate results lower than $69 \%$. In the literature it is assumed as very low effectiveness.

In the last stage of research author evaluated the effectiveness of created SOM model for European enterprises (Table 5).

Table 5. The results of the classification of European enterprises based on the testing sample of the SOM model (in parentheses is the number of misclassified firms)

\begin{tabular}{|l|c|c|c|c|c|c|c|c|}
\hline Years before & 15 & 14 & 13 & 12 & 11 & 10 & 9 & 8 \\
\hline Type I error & $\begin{array}{c}42.7 \% \\
(32)\end{array}$ & $\begin{array}{c}40 \% \\
(30)\end{array}$ & $\begin{array}{c}36 \% \\
(27)\end{array}$ & $\begin{array}{c}34.7 \% \\
(26)\end{array}$ & $\begin{array}{c}33.3 \% \\
(25)\end{array}$ & $\begin{array}{c}30.7 \% \\
(23)\end{array}$ & $\begin{array}{c}29.3 \% \\
(22)\end{array}$ & $\begin{array}{c}42.7 \% \\
(19)\end{array}$ \\
\hline Type II error & $\begin{array}{c}42.7 \% \\
(32)\end{array}$ & $\begin{array}{c}41.3 \% \\
(31)\end{array}$ & $\begin{array}{c}41.3 \% \\
(31)\end{array}$ & $\begin{array}{c}40 \% \\
(30)\end{array}$ & $\begin{array}{c}38.7 \% \\
(29)\end{array}$ & $\begin{array}{c}37.3 \% \\
(28)\end{array}$ & $\begin{array}{c}34.7 \% \\
(26)\end{array}$ & $\begin{array}{c}42.7 \% \\
(22)\end{array}$ \\
\hline Overall effect. & $57.33 \%$ & $59.33 \%$ & $61.33 \%$ & $62.67 \%$ & $64 \%$ & $66 \%$ & $68 \%$ & $57.33 \%$ \\
\hline Years before & 7 & 6 & 5 & 4 & 3 & 2 & 1 & \\
\hline Type I error & $\begin{array}{c}18.7 \% \\
(14)\end{array}$ & $\begin{array}{c}17.3 \% \\
(13)\end{array}$ & $\begin{array}{c}16 \% \\
(12)\end{array}$ & $\begin{array}{c}12 \% \\
(9)\end{array}$ & $\begin{array}{c}9.3 \% \\
(7)\end{array}$ & $\begin{array}{c}5.3 \% \\
(4)\end{array}$ & $\begin{array}{c}4.0 \% \\
(3)\end{array}$ & \\
\hline Type II error & $\begin{array}{c}22.7 \% \\
(17)\end{array}$ & $\begin{array}{c}21.3 \% \\
(16)\end{array}$ & $\begin{array}{c}18.7 \% \\
(14)\end{array}$ & $\begin{array}{c}16 \% \\
(12)\end{array}$ & $\begin{array}{c}12 \% \\
(9)\end{array}$ & $\begin{array}{c}10.7 \% \\
(8)\end{array}$ & $\begin{array}{c}6.7 \% \\
(5)\end{array}$ & \\
\hline Overall effect. & $79.33 \%$ & $80.67 \%$ & $82.67 \%$ & $86 \%$ & $89.33 \%$ & $92 \%$ & $94.67 \%$ & \\
\hline
\end{tabular}

The aim of such approach was to check if effectiveness of specialized SOM model differs much from effectiveness of more universal SOM model that was estimated for wide variety of enterprises from very different economic regions. Although the allocation of risk classes is different in the European SOM model, it can be seen that the effectiveness of this model is very similar to effectiveness of global SOM model. In most years (from $1^{\text {st }}$ to $15^{\text {th }}$ year prior bankruptcy) the specialized model is characterized by slightly better effectiveness (e.g. $94.67 \%$ versus $94.33 \%$ one year before, $92 \%$ versus $91.33 \%$ two years before, $86 \%$ versus $85 \%$ four years prior bankruptcy). It is confirmation that self-organizing map model has high abilities of adaptability. It means that model keeps high predictive abilities even in wide variety of economic conditions in different regions.

\section{Conclusions}

The presented study proves that a model of the self-organizing map can enhance prediction of financial failure in enterprises by showing the migration of risk classes that reflect not only a static snapshot of the financial situation but more importantly dynamic changes occurring in enterprises. Thus, this model identifies the long-term differences between nonbankrupt and future bankrupt enterprises. By examining the volatility of migration between risk classes, the model revealed the first symptoms of going into bankruptcy long before the 
real bankruptcy risk occurred in the firms, in a much shorter time than traditional forecasting models needed to predict such risk. This result proved the superiority of the new model.

To summarize, this study showed that the developed global SOM model can be used for the following:

- Forecasting bankruptcy risk (The model was highly effective in the short-term analysis (from $94.33 \%$ to $89.00 \%$ ) and in the long-term analysis during the forecasting period from four years to as long as seven years before bankruptcy (from $85.00 \%$ to 79.67\%);

- Tracking the trajectory of growth or decline of the company - in an example of one firm, the author showed that this model well visualizes the economic situation, making it easier to track the classification path of the financial standing of the enterprise in the long-term horizon of 15 years;

- Making better business decisions in the long term (10-15 years) - this model provides a good graphical tool to support managers in the decision-making process. A financial analyst can follow economic risks of a company on the map with insights into the patterns of bankrupt and non-bankrupt company development;

- The precise identification of the level of risk with improved stability of forecast effectiveness.

Moreover, the study proved that SOM model is very effective in two very different research approaches - in universal usage (with population of enterprises from different economic regions) and in specialized usage (with homogenous population of firms).

- It is worth to add that presented study can be used in several aspects:

- Early warning against deteriorating financial situation of an audited enterprise,

- Assessment of implementation of economic plans of company,

- Evaluation of the solvency of counterparties,

- Credit risk assessment by financial institutions,

- Risk assessment of buying company shares by individual and institutional investors in global stock exchanges.

At this point, it should be also emphasized that the proposed early warning model should only act as a tool to support evaluation of financial condition of the company and facilitate the decision making process associated with this assessment. The author's aim was not to develop an "application" to replace the use of various types of analyzes, such as a comprehensive economic analysis of particular areas of the company, or a SWOT analysis, etc. It is worth to add that in the study the wide variety of financial ratios covering the aspects of profitability, activity, debt and liquidity were used. The most crucial ratios in the process of forecasting the risk of bankruptcy are: the share of working capital in total assets (X2), current liquidity (X8), net return on total assets (X15), turnover of total assets (X7), covering degree of fixed assets by stockholders' equity and noncurrent liabilities (X6) and relation of total assets to total debts (X11).

The author is also aware of various limitations of the conducted study. The main difficulty is limited access to financial data of bankrupt enterprises. The ideal situation would be a possibility to develop this type of model separately for small and medium-sized companies and large companies, separately for the different sectors of the economy. Nevertheless, obtained results let set the future research directions. Author of this paper is going to continue this study by adding other indicators (for example, nonfinancial factors) to the early warning 
model. Knowing the long-term risk class migrations of non-bankrupt and bankrupt enterprises we can try to implement to the model such factors as fluctuations of exchange rates, growth rate of GDP or other macroeconomic factors that directly and indirectly can influence the financial risk of enterprises.

\section{Funding}

This work has been prepared within the grant project No. 2015/19/B/HS4/00377, “Trajectories of life and the collapse of companies in Poland and in the world - identification, evaluation and forecast". The research is funded by the National Science Center in Poland (Narodowe Centrum Nauki).

\section{References}

Acosta-González, E., \& Fernández-Rodríguez, F. (2014). Forecasting financial failure of firms via genetic algorithms. Computational Economics, 43, 133-157. https://doi.org/10.1007/s10614-013-9392-9

Agarwal, V., \& Taffler, R. (2007). Twenty-five years of the Taffler z-score model - does it really have predictive ability? Accounting and Business Research, 37(4). https://doi.org/10.1080/00014788.2007.9663313

Alaka, H. A., Oyedele, L. O., Owolabi, H. A., Kumar, V., Ajayi, S. O., Akinade, O. O., \& Bilal, M. (2018). Systematic review of bankruptcy prediction models: Towards a framework for tool selection. Expert Systems with Applications, 94, 164-184. https://doi.org/10.1016/j.eswa.2017.10.040

Altman, E. (1968). Financial ratios, discriminant analysis and the prediction of corporate bankruptcy. Journal of Finance, 23, 589-609. https://doi.org/10.1111/j.1540-6261.1968.tb00843.x

Altman, E. (2018). Applications of distress prediction models: What have we learned after 50 years from the Z-score models? International Journal of Financial Studies, 6(3), 70. https://doi.org/10.3390/ijfs6030070

Altman, E., \& Sabato, G. (2007). Modelling credit risk for SMEs - evidence from the US market. ABACUS, 43(3), 332-356. https://doi.org/10.1111/j.1467-6281.2007.00234.x

Argenti, J. (1976). Corporate collapse - the causes and symptoms. McGraw-Hill.

Barboza, F., Kimura, H., \& Altman, E. (2017). Machine learning models and bankruptcy prediction. Expert Systems with Applications, 83, 405-417. https://doi.org/10.1016/j.eswa.2017.04.006

Bluhm, Ch., Overbeck, L., \& Wagner, Ch. (2003). An introduction to credit risk modeling. Chapman \& Hall/CRC. https://doi.org/10.1201/9781420057362

Brabazon, A., \& O’Neil, M. (2004). Diagnosing corporate stability using grammatical evolution. Journal of Applied Mathematics and Computer Science, 1, 293-310.

Burgelman, R. (1991). Intraorganizational mortality-liabilities of newness and adolescence. Organization Science, 2(3), 239-262. https://doi.org/10.1287/orsc.2.3.239

Chen, N., Ribeiro, B., Vieira, A., \& Chen, A. (2013). Clustering and visualization of bankruptcy trajectory using self-organizing map. Expert Systems with Applications, 40(1), 385-393. https://doi.org/10.1016/j.eswa.2012.07.047

Delen, D., Kuzey, C., \& Uyar, A. (2013). Measuring firm performance using financial ratios: A decision tree approach. Expert Systems with Applications, (40), 3970-3983.

https://doi.org/10.1016/j.eswa.2013.01.012 
Dong, M. C., Tian, S., \& Chen, C. W. S. (2018). Predicting failure risk using financial ratios: Quantile hazard model approach. North American Journal of Economics and Finance, 44, 204-220. https://doi.org/10.1016/j.najef.2018.01.005

Fichman, M., \& Levintahl, D. (1991). Honeymoon and liability of adolescence- a new perspective on duration dependence in social and organizational relationship. Academy of Management Review, 16(2), 442-468. https://doi.org/10.5465/amr.1991.4278962

Flores-Jimeno, R., \& Jimeno-Garcia, I. (2017). Dynamic analysis of different business failure proccess. Problems and Perspective Management, 15(2), 486-499. https://doi.org/10.21511/ppm.15(si).2017.02

Gavurova, B., Packova, M., Misankova, M., \& Smrcka, L. (2017). Predictive potential and risks of selected bankruptcy prediction models in the Slovak business environment. Journal of Business Economics and Management, 18(6), 1156-1173. https://doi.org/10.3846/16111699.2017.1400461

Giannopoulos, G., \& Sigbjornsen, S. (2019). Prediction of bankruptcy using financial ratios in the Greek market. Theoretical Economics Letters, 9, 1114-1128. https://doi.org/10.4236/tel.2019.94072

Gilbert, C. (2005). Unbounding the structure of inertia - resource vs routine rigidity. Academy of Management Journal, 48(5), 741-763. https://doi.org/10.5465/amj.2005.18803920

Grice, J., \& Dugan, M. (2001). The limitations of bankruptcy prediction models - some cautions for the researcher. Review of Quantitative Finance and Accounting, 17, 151-166. https://doi.org/10.1023/A:1017973604789

Hambrick, D., \& D’Aveni, R. (1988). Large corporate failures as downward spirals. Administrative Science Quarterly, 33(1), 1-23. https://doi.org/10.2307/2392853

Hosaka, T. (2019). Bankruptcy prediction using imaged financial ratios and convolutional neural networks. Expert Systems with Applications, 117(1), 287-299. https://doi.org/10.1016/j.eswa.2018.09.039

Iturriaga, F. J., \& Sanz, I. P. (2015). Bankruptcy visualization and prediction using neural networks - a study of U.S. commercial banks. Expert Systems with Applications, 42(6), 2857-2869. https://doi.org/10.1016/j.eswa.2014.11.025

Jayasekera, R. (2018). Prediction of company failure: Past, present and promising directions for the future. International Review of Financial Analysis, 55, 196-208. https://doi.org/10.1016/j.irfa.2017.08.009

Jardin, P. (2015). Bankruptcy prediction using terminal failure processes. European Journal of Operational Research, 242(1), 286-303. https://doi.org/10.1016/j.ejor.2014.09.059

Jardin, P., \& Severin, E. (2011). Predicting corporate bankruptcy using a self-organizing map - an empirical study to improve the forecasting horizon of a financial failure model. Decision Support Systems, 51(3), 701-711. https://doi.org/10.1016/j.dss.2011.04.001

Johnson, G. (1988). Rethinking incrementalism. Strategic Management Journal, 9(1), 73-91. https://doi.org/10.1002/smj.4250090107

Kale, S., \& Arditi, D. (1998). Business failures-liabilities of newness, adolescence and smallness. Journal of Construction Engineering and Management, 124(6), 458-464.

https://doi.org/10.1061/(ASCE)0733-9364(1998)124:6(458)

Kiang, M., \& Kumar, A. (2001). An evaluation of self-organizing map networks as a robust alternative to factor analysis in data mining applications. Information System Research, 12(2), 177-194. https://doi.org/10.1287/isre.12.2.177.9696

Kohonen, T. (1982). Self-organized formation of topologically correct feature maps. Biological Cybernetics, 43(1), 141-152. https://doi.org/10.1007/BF00337288

Kumar, P. R., \& Ravi, V. (2007). Bankruptcy prediction in banks and firms via statistical and intelligent techniques - a review. European Journal of Operational Research, 180, 1-28.

https://doi.org/10.1016/j.ejor.2006.08.043 
Laitinen, E. (2007). Classification accuracy and correlation - LDA in failure prediction. European Journal of Operational Research, 183, 210-225. https://doi.org/10.1016/j.ejor.2006.09.054

Laitinen, E., \& Lukason, O. (2014). Do firm failure processes differ across countries: evidence from Finland and Estonia. Journal of Business Economics and Management, 15(5), 810-832. https://doi.org/10.3846/16111699.2013.791635

Laitinen, E., Lukason, O., \& Suvas, A. (2014). Behaviour of financial ratios in firm failure process: An international comparison. International Journal of Finance and Accounting, 3(2), 122-131.

Lensberg, T., Eilifsen, A., \& McKee, T. E. (2006). Bankruptcy theory development and classification via genetic programming. European Journal of Operational Research, 169, 677-697. https://doi.org/10.1016/j.ejor.2004.06.013

Li, L., \& Faff, R. (2019). Predicting corporate bankruptcy: What matters? International Review of Economics \& Finance, 62, 1-19. https://doi.org/10.1016/j.iref.2019.02.016

Liang, D., Lu, Ch., Tsai, Ch., \& Shih, G. (2016). Financial ratios and corporate governance indicators in bankruptcy prediction: A comprehensive study. European Journal of Operational Research, 252(2), 561-572. https://doi.org/10.1016/j.ejor.2016.01.012

Lin, F., Liang, D., Yeh, C. C., \& Huang, J. C. (2014). Novel feature selection methods to financial distress prediction. Expert Systems with Applications, 41, 2472-2483. https://doi.org/10.1016/j.eswa.2013.09.047

Lukason, O., \& Hoffman, R. (2014). Firm bankruptcy probability and causes - an integrated study. International Journal of Business and Management, 9(11), 80. https://doi.org/10.5539/ijbm.v9n11p80

Mihalovic, M. (2016). Performance comparison of multiple discriminant analysis and logit models in bankruptcy prediction. Economics and Sociology, 9(4), 101-118. https://doi.org/10.14254/2071-789X.2016/9-4/6

Moulton, W. \& Thomas, H. (1996). Business failure pathways - environmental stress and organizational response. Journal of Management, 2(4), 571-595. https://doi.org/10.1016/S0149-2063(96)90025-2

Ooghe, H., \& Balcaen, S. (2006). 35 years of studies on business failure - an overview of the classic statistical methodologies and their related problems. The British Accounting Review, 38, 63-93. https://doi.org/10.1016/j.bar.2005.09.001

Ooghe, H., \& Prijcker, S. (2008). Failure processes and causes of company bankruptcy - a typology. Management Decision, 46(2), 223-242. https://doi.org/10.1108/00251740810854131

Orsenigo, C., \& Vercellis, C. (2013). Linear versus nonlinear dimensionality reduction for banks credit rating prediction. Knowledge-Based Systems, 47, 14-22. https://doi.org/10.1016/j.knosys.2013.03.001

Psillaki, M., Tsolas, I. E., \& Margaritis, D. (2010). Evaluation of credit risk based on firm performance. European Journal of Operational Research, 201, 873-881. https://doi.org/10.1016/j.ejor.2009.03.032

Ptak-Chmielewska, A. (2019). Predicting micro-enterprise failures using data mining techniques. Journal of Risk and Financial Managament, 12, 1-17. https://doi.org/10.3390/jrfm12010030

Richardson, B., Nwankwo, S., \& Richardson, S. (1994). Understanding the causes of business failure crises. Management Decision Journal, 32(4), 9-22. https://doi.org/10.1108/00251749410058635

Sayari, N., \& Mugan, C.D. (2017). Industry specific financial distress modeling. Business Research Quarterly, 20, 45-62. https://doi.org/10.1016/j.brq.2016.03.003

Shimko, D. (2004). Credit risk - models and management. Barra Risk Books.

Schonfeld, J., Kudej, M., \& Smrcka, L. (2018). Financial health of enterprises introducing safeguard procedure based on bankruptcy models. Journal of Business Economics and Management, 19, 692-705. https://doi.org/10.3846/jbem.2018.7063

Sun, J., Li, H., Huang, Q., \& He, K. (2014). Predicting financial distress and corporate failure - a review from the state-of-the-art definitions, modeling, sampling, and featuring approaches. KnowledgeBased Systems, 57, 41-56. https://doi.org/10.1016/j.knosys.2013.12.006 
Tian, S., Yu, Y., \& Guo, H. (2015). Variable selection and corporate bankruptcy forecasts. Journal of Banking \& Finance, 52, 89-100. https://doi.org/10.1016/j.jbankfin.2014.12.003

Tian, S., \& Yu, Y. (2017). Financial ratios and bankruptcy predictions: An international evidence. International Review of Economics and Finance, 51, 510-526. https://doi.org/10.1016/j.iref.2017.07.025

Tsai, Ch. (2014). Combining cluster analysis with classifier ensembles to predict financial distress. Information Fusion, 16, 46-58. https://doi.org/10.1016/j.inffus.2011.12.001

Utterback, J., \& Suarez, F. (1993). Patterns of industrial evolution, dominant desing, and firms' survival. In R. Burgelman, Research on technological innovation, management policy (Vol. 5, pp. 47-87). Greenwich Press.

Wilner, B. (2000). The exploitation of relationships in financial distress - The case of trade credit. The Journal of Finance, 55(1). https://doi.org/10.1111/0022-1082.00203

Wiseman, R., \& Bromiley, P. (1996). Toward a model of risk in declining organizations. Organization Science, 7(5), 524-543. https://doi.org/10.1287/orsc.7.5.524

Wu, Y., Gaunt, C., \& Gray, S. (2010). A comparison of alternative bankruptcy prediction models. Journal of Contemporary Accounting \& Economics, 6, 34-45. https://doi.org/10.1016/j.jcae.2010.04.002

Xiao, Z., Yang, X., Pang, Y., \& Dang, X. (2012). The prediction for listed companies' financial distress by using multiple prediction methods with rough set and Dempster-Shafer evidence theory. Knowledge-Based Systems, 26, 196-206. https://doi.org/10.1016/j.knosys.2011.08.001

Zammuto, R., \& Cameron, K. (1985). Environmental decline and organizational response. Research in Organizational Behavior, 7, 223-262.

Zapranis, A., \& Ginoglou, D. (2000). Forecasting corporate failure with neural network approach: The Greek case. Journal of Financial Management \& Analysis, 13(2), 11-21. 